\title{
Prospects of damaged calcareous spring systems in temperate Europe: Can we restore travertine-marl deposition?
}

\author{
Ab Grootjans • Marc Bulte • Lesław Wolejko • \\ Mara Pakalne • Bikila Dullo • Nelly Eck • \\ Christian Fritz
}

Received: 22 October 2013 / Accepted: 10 March 2015 / Published online: 29 May 2015

(C) The Author(s) 2015. This article is published with open access at Springerlink.com

\begin{abstract}
Calcareous mires are peat forming systems fed by calcareous groundwater that regularly deposit travertine $\left(\mathrm{CaCO}_{3}\right)$ on the soil surface or in small pools that are present in such mires. At present almost all calcareous mires in Poland are degraded, most often by land use, which has led to disturbances in local hydrological systems. An experiment was set up in a degraded spring mire in western Poland to test if travertine deposition could be restored. Trees were removed to increase surface water temperatures, and a system of open water pools was constructed to measure $\mathrm{CaCO}_{3}$ deposition in the surface water. We also studied three references systems with active $\mathrm{CaCO}_{3}$ deposition in Poland and in Latvia. The pools in the restoration site
\end{abstract}

A. Grootjans $(\bowtie) \cdot$ M. Bulte $\cdot$ B. Dullo $\cdot$ C. Fritz Centre for Energy and Environmental Studies, University of Groningen, Nijenborgh 4, 9747 AG Groningen, The Netherlands

e-mail: A.P.Grootjans@rug.nl

A. Grootjans $\cdot$ C. Fritz

Department of Aquatic Ecology, Institute for Water and Wetland Research (IWWR), Radboud University Nijmegen, Heyendaalseweg 135, 6525 AJ Nijmegen, The Netherlands

L. Wołejko

West Pomeranian University of Technology in Szczecin, Slowackiego 17, 71-434 Szczecin, Poland

M. Pakalne

University of Riga, Riga, Latvia

N. Eck

Community and Conservation Ecology group, University of Groningen, Groningen, The Netherlands in Poland showed very little $\mathrm{CaCO}_{3}$ deposition (less than $0.2 \mu \mathrm{g} \cdot \mathrm{cm}^{-2} \cdot \mathrm{d}^{-1}$ ), while the Polish reference site had significantly higher, but still modest, rates of $\mathrm{CaCO}_{3}$ deposition (ca $0.8 \mu \mathrm{g} \cdot \mathrm{cm}^{-2} \cdot \mathrm{d}^{-1}$ ). At the reference sites in Latvia, we measured considerable $\mathrm{CaCO}_{3}$ deposition (up to $8 \mu \mathrm{g} \cdot \mathrm{cm}^{-2} \cdot \mathrm{d}^{-1}$ ). Five years after the restoration measures in the Polish restoration site had been carried out, the vegetation showed little resemblance to the vegetation in spring systems with active calcite deposition in Poland and Latvia. Water analyses showed that the water in our restoration project was not supersaturated by calcite and had very low $\mathrm{CO}_{2}$ concentrations compared to the reference areas. The $\mathrm{CO}_{2}$ concentrations in the pool seemed a good predictor for $\mathrm{CaCO}_{3}$ deposition, better than $\mathrm{Ca}^{2+}$ concentrations. Changes in ground water flows in the source area could have been responsible for the loss of supersaturated groundwater at our restoration site. Our study showed that efforts to restore former calcareous mires can be frustrated when groundwater flow paths have been altered.

Keywords alder forest $\cdot \mathrm{CaCO}_{3}$ deposition · hydrology . Latvia $\cdot$ Poland

\section{Introduction}

A calcareous fen is a peat forming ecosystem (mire) that is fed by calcareous groundwater or surface water and is regularly depositing calcite on the surface of the mire. In literature this deposited $\mathrm{CaCO}_{3}$ is sometimes called 'marl' or 'calcareous tufa', indicating the softer and 
clastic $\mathrm{CaCO}_{3}$ deposits in contrast to 'travertine', which usually refers to firmer, crystalline types of deposits. In this study we will use the term travertine as a synonym to 'travertine-marl', proposed by Herman and Hubbard (1990). Travertine thus includes both types of calcite deposition (soft and firm; see also Pentecost 2005).

The nutrient availability in calcareous fens is very low, but its biodiversity is usually very high (Wassen et al. 2005). Together with other fen types, such as rich and poor fens, calcareous fens are among the most floristically diverse of all wetland types, supporting a large number of rare bryophytes and vascular plant species, as well as uncommon animals (Wheeler and Giller 1982; Bedford and Godwin 2003; Hájková and Hájek 2003). Nowadays, calcareous fens are critically endangered in most of Europe and the USA due to drainage in surrounding areas. groundwater abstraction in aquifers, eutrophication or changes in land use, such as planting pine plantations in infiltration areas (Bedford and Godwin 2003; Hájek et al. 2002; Grootjans et al. 2006; Middleton et al. 2006).

Peat formation can only continue when groundwater discharge is slow but continuous. Rapid (point) outflow of groundwater would cause erosion. The topology of the fen is, therefore, dependent on the nature of the subsurface substrate and its hydrology (Amon et al. 2002). Calcareous fens can exist even when potential evapotranspiration is 3.5 times higher than precipitation (Cooper 1995), since the fens receive groundwater almost continuously from a wider infiltration area. However, the intensity of the discharging water should not be too high, because otherwise erosion of the peat system will occur (Wołejko et al. 1994).

Calcium carbonate precipitation in freshwater environments is governed by four key factors: (1) the $\mathrm{Ca}^{2+}$ concentration. (2) the concentration of dissolved inorganic carbon, (3) the $\mathrm{pH}$ and (4) the availability of nucleation sites (Wright and Oren 2005). The primary reason for calcite precipitation from discharging groundwater is equalization of the groundwater $\mathrm{CO}_{2}$ pressure with atmospheric $\mathrm{CO}_{2}$ pressure, called 'outgassing'. Several other processes can contribute to the loss of $\mathrm{CO}_{2}$ from the groundwater: (1) temperature, (2) evaporation and (3) activity of living organisms. $\mathrm{CO}_{2}$ can also be withdrawn to meet photosynthetic demands of plants. moss species, algae and bacteria (Pentecost 2005). Water plants that are well known for stimulating $\mathrm{CaCO}_{3}$ deposition are Chara or Potamogeton species (Cooper 1995; Futyma and Miller
2001), and they are primarily responsible for aquatic $\mathrm{CaCO}_{3}$ precipitation of lake marl in lakes (Vreeken 1981). The concentration of $\mathrm{CO}_{2}$ in the water is strongly influenced by temperature. High temperatures will release much $\mathrm{CO}_{2}$, which will enhance $\mathrm{CaCO}_{3}$ precipitation (Amon et al. 2002).

Almendinger and Leete (1998) observed both calcite dissolution and precipitation. Their results suggested that carbonate solubility is sensitive to small changes in water chemistry caused by rainfall or evaporation. The rate of $\mathrm{CaCO}_{3}$ deposition can vary even within one season (Komor 1994) and also between day and night (Pentecost 2005). Several authors have observed that cyclic shifts may occur between peat formation and $\mathrm{CaCO}_{3}$ precipitation (Succow and Joosten 2001; Dobrowolski et al. 2005; Miner and Ketterling 2003). Since the rate of $\mathrm{CaCO}_{3}$ deposition is strongly temperature-dependent, several authors have suggested that these cyclic shifts have been triggered by changes in the climate (Vreeken 1981; Goudie et al. 1993; Frank et al. 2000; Dobrowolski et al. 2005). Some authors suggest that decalcification of landscapes during the Holocene, depleting calcium carbonate stocks, could have been a major factor in shifts from marl to peat accumulation (Vreeken 1981). Such decalcification of landscapes has indeed occurred in some parts of Western Europe where the last glaciation occurred ca 180,000 years ago. However, the sudden stop in $\mathrm{CaCO}_{3}$ formation in lowland peatlands of Poland and eastern Germany, cannot be explained by deep decalcification of landscapes, since the retreat of the glaciers here occurred only 13,000 years ago (Succow and Joosten 2001) and because calcareous soils are still common here.

Land use changes that affect microbial activity in soils of recharge areas can lead to changes in soil respiration (change in $\mathrm{CO}_{2}$ concentration) and consequently affect $\mathrm{CaCO}_{3}$ precipitation (Pentecost 2005). Both forestation and deforestation and also agricultural activities such as ploughing and fertilization in the catchment are, therefore, closely related to $\mathrm{CaCO}_{3}$ precipitation in calcareous fens. At many Central-European localities, the onset of $\mathrm{CaCO}_{3}$ deposition has been shown to coincide with settlement and deforestation (Hájek et al. 2002; Hájkova et al. 2011). In eastern Germany (Succow and Joosten 2001) and in Latvia (Pakalne and Čakare 2001), calcareous fens with active $\mathrm{CaCO}_{3}$ deposition still exist in the lowlands, indicating that climatological change was not solely responsible for the decline of calcite depositing mires in Poland. It suggests that forestation 
and associated hydrological changes could be more important factors for the recent decline of $\mathrm{CaCO}_{3}$ depositing fens in Eastern Europe.

Many spring ecosystems in the German and Polish lowlands are currently situated in forest areas and covered by trees. They do not accumulate peat anymore, due to eroding spring rivulets that have developed after hydrological disturbances (Wołejko et al. 1994). Over time they have shifted from nutrient poor calcareous mires into eutrophic eroding ecosystems dominated by tall herbs, such as Urtica dioica, Phragmites australis and Carex acutiformis, in which the availability of nutrients, in particular phosphates, is very high. Wołejko (2001) described many of such degrading spring mires with fossil travertine deposits, indicating that $\mathrm{CaCO}_{3}$ deposition had occurred in the past.

Restoration of such degraded spring systems requires not only rewetting, but also more optimal conditions for travertine deposition, for instance higher temperatures in the mire. Our research in treeless calcareous spring mires in Slovakia (Grootjans et al. 2005, 2006, 2012) suggested that high temperatures in the pool systems increased $\mathrm{CaCO}_{3}$ deposition considerably. Increasing temperatures decrease $\mathrm{CO}_{2}$ concentrations in the water, and in supersaturated water this will lead to $\mathrm{CaCO}_{3}$ deposition (Pentecost 2005).

In the present study we discuss an attempt to restore $\mathrm{CaCO}_{3}$ deposition in such a degraded spring system in western Poland by first rewetting the mire and then removing trees in order to allow warming up of the discharging groundwater. We also studied intact calcareous spring systems in Poland and Latvia as reference systems.

The aim of this study is to investigate whether we can restore nutrient-poor (mesotrophic) plant communities with a high biodiversity in degraded and eutrophic spring mires by stimulating $\mathrm{CaCO}_{3}$ deposition within an eroding mire, thus stabilizing nutrient cycling at a low level (Boyer and Wheeler 1989; Lamers et al. 2002).

We formulated the following questions and hypotheses:

1. Can we restore $\mathrm{CaCO}_{3}$ deposition by cutting trees and by creating a cascade of artificial pools within a spring system? We hypothesize that the pools will slow down flow velocities in the mire and that the felling of trees will allow warming up of the surface water, thus stimulating $\mathrm{CaCO}_{3}$ deposition in the pools.
2. Does rewetting and increased light availability lead to a shift from eutrophic to mesotrophic plant communities? We hypothesize that after restoring calcite precipitation in the spring system the species composition of the vegetation will reflect less eutrophic conditions.

\section{Study sites}

The restoration site in Poland is situated in the Ina River valley near the town of Recz in north-western Poland (Fig. 1). The Polish reference site is situated in northern Poland near the town of Złotow. The Latvian reference sites are situated in the Slitere National Park.

Poland

\section{Degraded spring mire}

The degraded spring mire near the town of Recz (N 531', $\mathrm{E} 15^{\circ} 35^{\prime}$ ) is situated on a steep slope that receives groundwater from an aquifer that is forced to discharge water near a geological fault. The mire of less than 1 ha has been degraded due to drainage and erosion. The top layer of the peat was strongly decomposed with few recognizable macrofossils mostly sedges and (brown) moss remnants. The peat was inter-layered with silt or sand layers. Fossil travertine deposits were found at various sites in the mire, at about $40-50 \mathrm{~cm}$ and at $130-150 \mathrm{~cm}$ below the surface and at the borders of the mire, much small particles of travertine were found in the soil. There are several other degrading spring systems in the same valley. In the past more spring systems were present, but they have been changes into fish ponds. The bottom of some of these fishponds comprise of a small layer of travertine-marl, which appear to have been deposited recently.

Groundwater flows have also been changed due to geological coring in the areas, which had led to the development of a new small spring system. Local people have mentioned the occurrence spontaneous shifts in groundwater discharge from one place to another.

\section{Reference site with active travertine formation}

The study site Złotow (N 53⒋ $41^{\prime}$, E $17^{\circ} 23^{\prime}$ ) consists of ca 1 ha of fen vegetation dominated by sedges (Carex diandra and Carex rostrata). It is situated almost 10 kilometres from the town of Złotow in northern Poland. The site is bordering a small river. The water level in this 
Fig. 1 Location of study areas. 1 - restoration site, Recz, Poland. 2 - reference site, Złotow, Poland. 3 - reference sites, Slitere National Park, Latvia.

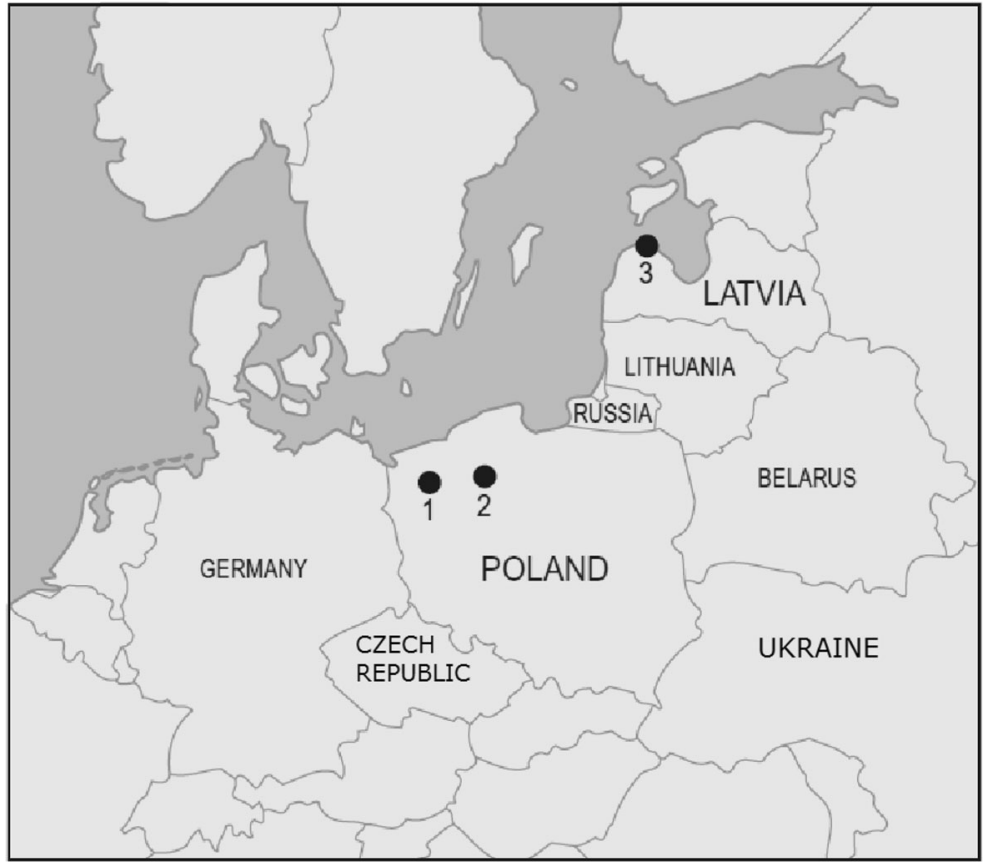

river has been raised following the construction of a water reservoir. As a consequence the study site has been rewetted as well. The site has been mown in the past, but it has been abandoned after the rewetting has occurred. The thickness of the peat is $2-3 \mathrm{~m}$. We found distinct (fossil) layers of travertine in the peat, interspaced with rather well preserved layers of fen peat. The mire has been affected by human activity, since it has been mown in the past. The peat is much less decomposed compared to the spring mire at Recz. Active precipitation of calcite is still taking place on leaves of living bryophytes.

\section{Latvia}

\section{Reference spring mire in a forest}

The field sites in Latvia were situated in the northeastern part of Latvia in the Slitere National Park (N 57 $37^{\prime}, \mathrm{E} 22^{\circ} 17^{\prime}$ ). One site of less than 0.25 was situated in a forest with active travertine deposition mostly on living bryophytes (e.g. Brachythecium rivulare). The other reference site (Mazirbe) was situated in a peat cut of ca 0.5 ha, where peat had been removed exposing underlying travertine layers. Here a well developed Caricion davallianae vegetation with many rare and endangered plant species had developed on the remnants of travertine deposits. At this site, we only studied the vegetation composition.

\section{Material and methods}

\section{Restoration measures}

At the restoration site at Recz, a wooden dam was built in 2004 close to the outflow of the mire in order to rewet the spring mire and to reduce the flow of surface water in the mire (Fig. 1,2). In addition, practically all trees were cut in order to reduce shading and to increase the temperature on the mire surface.

\section{Set-up of experimental pools}

At the restoration site at Recz and at in the reference sites at Złotow and in the Slitere National Park, pools were dug to measure $\mathrm{CaCO}_{3}$ deposition and water chemistry parameters.

At each site, 6 pools were dug in two transects $\left(\mathrm{A}_{1-3}\right.$ and $\mathrm{B}_{1-3}$ ) with an average depth of 20-30 cm (Fig. 2). In the Slitere National Park, only one row of pools $\left(\mathrm{A}_{1-3}\right)$ was dug due to the small area available. The pools were $1 \times 1 \mathrm{~m}$ with a space of $1.5 \mathrm{~m}$ between the rows of pools. After 5 years the vegetation was described, and 6 new 
Fig. 2 Schematic set-up of the experimental pools $\left(\mathrm{A}_{1-3}\right.$ and $\left.\mathrm{B}_{1-3}\right)$ at Recz and Złotow in which $\mathrm{CaCO}_{3}$ deposition was measured. The upslope pools are situated in the seepage zone and attract most of the groundwater. Arrows indicate the direction of groundwater flow.

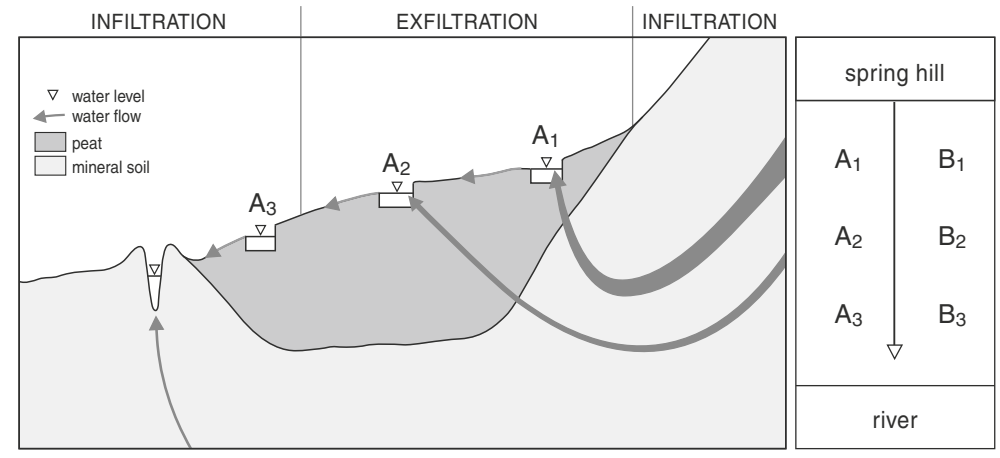

pools were dug to measure travertine deposition and also the chemical composition of the surface water. Ground water was sampled from a piezosmeter with filters at $40-50$ or $90-100 \mathrm{~cm}$ below the surface depending on the depth of the peat layer. They were placed upstream of the pools to capture the incoming groundwater before it escaped to the surface and the pools. Temperature, EC and $\mathrm{pH}$ in the pools were measured with a portable temperature/EC device (WTW Retsch) and a portable $\mathrm{pH}$ meter (Sentron 1001).

Water analyses in the laboratory

Ground- and surface water was sampled in Poland in July 2008 and in Latvia in July 2009 using PVC bottles, which were filled to the brim. In total 15 surface water samples were taken (one per pool) and 10 groundwater samples. For $\mathrm{CO}_{2}$ measurements glass bottles were used, which were filled to about two-thirds using gas-tight tubing and porous cups. The samples were stored at $4^{\circ} \mathrm{C}$ in the dark before analyses in the laboratory. Total inorganic carbon (TIC; bicarbonate and $\mathrm{CO}_{2}$ ) was measured with an infrared gas analyser (IRGA; ABB Advance Optima). $\mathrm{Ca}$ and total $\mathrm{S}$ concentrations in the water were measured using Inductively Coupled Plasma - Optic Emission Spectrometry (ICP-OES; Techno Electron Cooperation). Chloride concentrations were measured calorimetrically (Bran+Luebbe AutoAnalyzer 3).

\section{$\mathrm{CaCO}_{3}$ deposition}

Travertine deposition was measured using microscope slides (Lu et al. 2000 ) of $76 \times 26 \times 1 \mathrm{~mm}$, which were pre-treated in $1 \mathrm{M} \mathrm{HCl}$ for 24 hours. These slides, with 8 replicates per pool, were installed in the pools below the water level using small floating sponges. The microscope slides in the pools were recollected after 20
(Latvia) and 26 days (Poland), stored in a slide box to dry and analysed in the laboratory. The amount of calcium after drying was determined by dissolving the deposited calcium in $50 \mathrm{ml}$ of $1 \mathrm{M} \mathrm{HCl}$ by shaking it overnight. One $\mathrm{ml}$ of the solution was dissolved with $2.5 \mathrm{ml}$ of $\mathrm{LaNO}_{3}$ and $1.5 \mathrm{ml}$ of distilled water. Then the sample was analysed with the atomic absorption spectrophotometer (AAS).

Vegetation

At all experiment sites in Poland and Latvia the species composition and cover of individual species was assessed in relevés of 2 by 2 metres. In 2008, 10 relevés were made at the experimental restoration site of Recz in a wet alder forest. Seventeen relevés were described in 2004 before the restoration was carried out at degraded alder forest sites. In the calcareous fen at Złotow, 8 relevés were described in 2008.

At Latvia, 6 relevés were taken from the travertine depositing site in an alder forest in 2008 and 5 from the treeless calcareous fen in Mazirbe. Although we did not have sufficient data on travertine deposition and water composition to compare with the other references, we included the vegetation data in the DCA analysis because the vegetation composition is very close to the target of mesotrophic calcareous fens (see also Grootjans et al. 2012).

\section{Statistical analyses}

Variations in experimental pools of travertine deposition, calcium concentration and saturation index (SI), respectively, were tested using linear models in $\mathrm{R}$ version 2.14.1 (R Development Core Team 2009) using a nested approach. Results are presented in form of an ANOVA table. Pool number (1-3) was a fixed factors 
and site (Recz, Złotow, Slitere) a random factor. Block (individual transect) was assigned as fixed nesting factor. We log-transformed travertine deposition and calcium concentrations before analysis. The spatial replicates $(n=8)$ of travertine deposition where pooled so that analysis were performed of their means. Model simplification to a minimal adequate model was based on AIC (Akaike Information Criterion; Sakamoto et al. 1986) after backward selection using the likelihood ratio test. Linear models were sufficient to account for the variance structure in the data. To account for autocorrelation between carbon dioxide, TIC (total inorganic carbon) and calcium (Table 1) we calculated the Pearson coefficients between these variables in $\mathrm{R}$ version 2.14.1.

Vegetation data were analysed by Detrended Canonical Analysis implemented in CANOCO for Windows 4.5 (ter Braak and Šmilauer 2002). We chose DCA because environmental data were not available for each relevé. Moss species and juvenile trees were included in the analysis. The cover percentages of species were square root transformed to reduce the effect of dominant species. We downweighted rare species $(n<3$ in the dataset).

\section{Results}

\section{Water composition}

In the experimental pools in the Recz mire, the $\mathrm{CO}_{2}$ concentrations in the surface water were very low (Table 1, Fig. 4). Also the calcium and EC values in the experimental pools were lower than those measured in pools at reference sites in Poland and Latvia. The sulfur (mainly sulfate) concentrations in the Recz site were all higher than at the Złotow reference and the Slitere Forest site. At Złotow the calcium concentrations and EC values in the surface water showed a decline when moving away from the spring, indicating a loss of calcium from the surface water. In transect $\mathrm{A}$, this decline in calcium was associated with a drop in $\mathrm{CO}_{2}$ concentration. In transect B, this was not the case.

The three experimental pools in the Slitere Forest showed a large drop in $\mathrm{CO}_{2}$ concentration going down slope from the upper pool in the spring area to the lower one at the bottom of the spring mire. This is associated with a rise in $\mathrm{pH}$, but not with a clear decrease in calcium concentrations even though the $\mathrm{EC}$ values were lower.

The temperature of the groundwater and surface water samples in the experimental sites at Recz were quite low (ca 9-12 ${ }^{\circ} \mathrm{C}$ ) and comparable to the temperatures measure in the Slitere National Park. The temperatures of surface water in the experimental pools at Złotow were much higher $\left(\mathrm{ca} 20^{\circ} \mathrm{C}\right)$. Also the temperatures of the groundwater samples in Złotow were higher than at Recz and in the Slitere National Park.

Calculation of the saturation index for calcite showed that the surface water at Recz is in equilibrium with the calcite in the soil $\left(\mathrm{SI}_{\text {calcite }}\right.$ between -1 and 0.3$)$. Values higher than 0.3 indicate that the water is supersaturated for calcite. The water at Złotow is generally supersaturated $\left(\mathrm{SI}_{\text {calcite }}>0.3\right)$, and the same is true for the upstream pool in the Slitere National Park that attracted much groundwater.

The ground water at Slitere had high concentrations of $\mathrm{Ca}^{2+}$ (Table 1). $\mathrm{Mg}^{2+}$ and $\mathrm{HCO}_{3}^{-}$(not shown), and in particular the $\mathrm{CO}_{2}$ concentrations were very high. At Recz the concentration of almost all dissolved minerals (except sulfate) were low.

\section{$\mathrm{CaCO}_{3}$ deposition}

Calcite deposition in the different samples sites was significantly different. In the experimental cascade of pools at Recz, the $\mathrm{CaCO}_{3}$ deposition values were very low $\left(0.1-0.2 \mu \mathrm{g} \cdot \mathrm{cm}^{-2} \cdot \mathrm{d}^{-1}\right)$ compared to all other reference sites (Fig. 3). The values were very close to the back ground values (ca $0.1 \mu \mathrm{g} \cdot \mathrm{cm}^{-2} \cdot \mathrm{d}^{-1}$ ), due to measuring dissolved calcium in the surface water.

The Latvian reference site in the Slitere Forest showed higher values of $\mathrm{CaCO}_{3}$ deposition than the Polish sites (Fig. 3). Here the highest deposition values were found in the pool which was closest to the incoming groundwater $\left(\mathrm{A}_{1}\right)$. A distinct drop in calcite deposition was measured down slope of the first pool. At the Polish reference site Złotow, the deposition of $\mathrm{CaCO}_{3}$ in the experimental pools was significantly higher than at Recz (Table 2). The highest deposition rates were measured close to the springs on the valley slope in transect A. At the bottom of the slope, the pools showed significantly $(P=0.038)$ less deposition than the uppermost pools (i.e. A1 and B1) and the central pools (i.e. A2 and B2).

Positive correlation between $\mathrm{CaCO}_{3}$ deposition and $\mathrm{CO}_{2}$

$\mathrm{CaCO}_{3}$ deposition was best explained by $\mathrm{CO}_{2}$ concentrations in experimental pools (Table $1 ;$ d.f. $=1,12$; $\left.F=32.70 ; P<0.01 ; R^{2}=0.76\right)$. Variables like Total inorganic carbon (TIC), Si-index and $\mathrm{Ca}^{2+}$ were more 
Table 1 Composition of ground and surface water in the experimental area and in reference areas in Poland and Latvia. Recz - experimental area at Recz (Poland). Złot - reference area Złotow in Poland. Slit - reference area Slitere Forest, Latvia.

\begin{tabular}{|c|c|c|c|c|c|c|c|c|}
\hline Location & Water type & $\mathrm{pH}$ & $\begin{array}{l}\text { Temp } \\
{ }^{\circ} \mathrm{C}\end{array}$ & $\begin{array}{l}\mathrm{Cl} \\
\mu \mathrm{mol} .1^{-1}\end{array}$ & $\begin{array}{l}\text { SO4 } \\
\mu \mathrm{mol} \cdot 1^{-1}\end{array}$ & $\begin{array}{l}\mathrm{CO} 2 \\
\mu \mathrm{mol} \cdot 1^{-1}\end{array}$ & $\begin{array}{l}\mathrm{Ca} \\
\mu \mathrm{mol} \cdot 1^{-1}\end{array}$ & SI-index \\
\hline Recz-A1 & Surface & 7.7 & 9.3 & 163 & 196 & 85 & 1,479 & 0.11 \\
\hline Recz-A2 & Surface & 6.9 & 10.9 & 160 & 190 & 373 & 1,492 & -0.62 \\
\hline Recz-A3 & Surface & 7.7 & 12.2 & 167 & 197 & 87 & 1,513 & 0.15 \\
\hline Recz-B1 & Surface & 7.4 & 10.9 & 167 & 191 & 170 & 1,502 & -0.19 \\
\hline Recz-B2 & Surface & 7.5 & 11.4 & 167 & 188 & 185 & 1,516 & -0.06 \\
\hline Recz-B3 & Surface & 7.3 & 12.4 & 167 & 184 & 212 & 1,516 & -0.23 \\
\hline Złot-A1 & Surface & 7.3 & 18.8 & 167 & 13 & 564 & 3,146 & 0.49 \\
\hline Złot-A2 & Surface & 7.3 & 22 & 206 & 12 & 280 & 3,114 & 0.55 \\
\hline Złot-A3 & Surface & 7.2 & 22.4 & 497 & 32 & 403 & 2,543 & 0.32 \\
\hline Złot-B1 & Surface & 7.6 & 19.8 & 263 & 42 & 393 & 2,245 & 0.5 \\
\hline Złot-B2 & Surface & 7.3 & 19.7 & 309 & 108 & 381 & 2,002 & 0.1 \\
\hline Złot-B3 & Surface & 7.4 & 23.5 & 323 & 111 & 310 & 2,259 & 0.34 \\
\hline Slit A1 & Surface & 6.8 & 11.6 & 151 & 53 & 3,390 & 3,041 & 0.35 \\
\hline Slit A2 & Surface & 7.2 & 12.1 & 131 & 98 & 950 & 3,463 & 0.07 \\
\hline Slit A3 & Surface & 7.4 & 11.6 & 182 & 72 & 598 & 3,051 & -0.08 \\
\hline Recz-1 & Ground & 7.2 & 9.0 & 181 & 215 & 207 & 1,565 & -0.33 \\
\hline Recz-2 & Ground & 7.4 & 10.0 & 170 & 195 & 147 & 1,564 & -0.12 \\
\hline Recz-3 & Ground & 7.4 & 10.0 & 185 & 182 & 166 & 1,596 & -0.13 \\
\hline Złot-5 & Ground & 7.5 & 15.0 & 178 & 28 & 219 & 2,146 & 0.32 \\
\hline Złot-6 & Ground & 7.4 & 15.0 & 217 & 5 & 266 & 2,161 & 0.28 \\
\hline Złot-7 & Ground & 7.5 & 15.0 & 263 & 7 & 254 & 2,937 & 0.63 \\
\hline Złot-8 & Ground & 7.3 & 15.0 & 280 & 7 & 731 & 4,207 & 0.67 \\
\hline Złot-9 & Ground & 7.2 & 15.0 & 305 & 7 & 531 & 2,111 & -0.03 \\
\hline Slit1 & Ground & 6.9 & 11.2 & 153 & 20 & 984 & 3,535 & 0.10 \\
\hline Slit2 & Ground & 7.5 & 10.0 & 117 & 112 & 264 & 2,777 & 0.51 \\
\hline
\end{tabular}

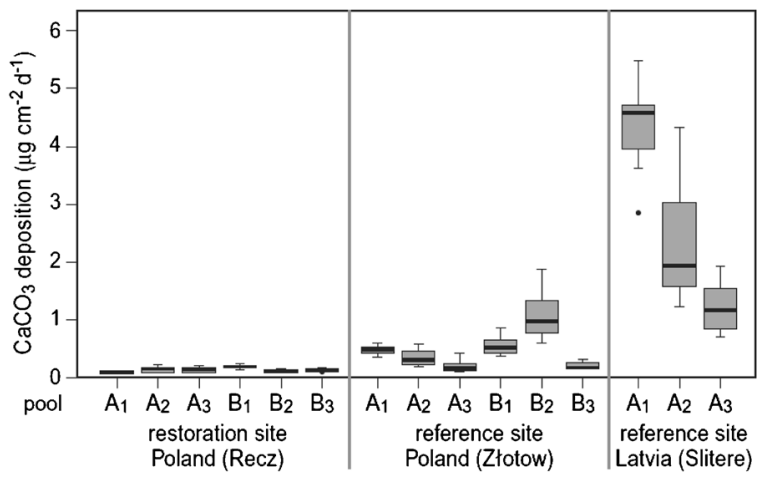

Fig. 3 Box plots of $\mathrm{CaCO}_{3}$ deposition in $\mu \mathrm{g} \mathrm{Ca}{ }^{2+} \mathrm{cm}^{2} \cdot \mathrm{d}^{-1}$. measured on microscope slides $(n=8$ per pool) in experimental pools in Polish and Latvian spring mires. The boxes (Tukey boxplot) comprise of the $25 \%$ quartile, the median (solid black line) and the $75 \%$ quartile. Whiskers represent data within 1.5 times the interquartile range from the box. Data outside the whiskers are respectively higher or lower. weakly correlated to travertine deposition rates than $\mathrm{CO}_{2}$ concentrations in experimental pools. Furthermore, we found that $\mathrm{CO}_{2}$, TIC and $\mathrm{Ca}^{2+}$ were auto-correlated with Pearson coefficients above 0.7 . Our study suggests that $\mathrm{CO}_{2}$ is a good predictor for travertine-marl deposition in the experimental pools.

\section{Vegetation}

The species composition of the restoration site reflects slightly wetter conditions than the unrestored alder forest 5 years after the restoration measures had been carried out. The site had developed a high cover of Carex acutiformis, Scrophularia umbrosa, Carex paniculata and in the pools also with much Lemna minor. Cadamine amara and Brachythecium rivulare had a low cover. The two unrestored alder forests close 
Table 2 ANOVA table presenting results from linear model. We tested the effects of site and pool sequence on average chalk deposition in pools, calcium concentration in pool water and the Si-index of pool water samples, respectively. Data shown in Fig. 3 and Table $\mathbf{1 .}$

\begin{tabular}{|c|c|c|c|c|c|c|c|c|}
\hline Variable & d.f. & $F$ & Sign. & $R^{2}$ & $\begin{array}{l}F \text {-values } \\
\text { Block }\end{array}$ & $\begin{array}{l}F \text {-values } \\
\text { Site }\end{array}$ & $\begin{array}{l}F \text {-values } \\
\text { Pool }\end{array}$ & $\begin{array}{l}F \text {-values } \\
\text { Site } \times \text { Pool }\end{array}$ \\
\hline Chalk deposition & 3,11 & 30.09 & $<0.001$ & 0.89 & ns & $42.26^{* * *}$ & $5.75^{*}$ & ns \\
\hline Ca pool water & 3,11 & 43.36 & $<0.001$ & 0.90 & $5.63 *$ & $62.22 * * *$ & ns & ns \\
\hline SI-index & 2,12 & 7.85 & $<0.001$ & 0.49 & ns & $7.85^{* *}$ & $\mathrm{~ns}$ & $\mathrm{~ns}$ \\
\hline
\end{tabular}

to the rewetted site also had Carex acutiformis, Cardamine amara and Chrysosplenium alternifolium, but also a high proportion of tall herbs such as Urtica dioica and Impatiens parviflora.

The reference site with travertine deposition at Złotow was characterized by a high proportion of lowproductive sedges, such as Carex diandra and Carex rostrata, a high cover of brown moss species, mostly Calliergonella cuspidata and also some species of spring fens, such as Cardamine amara.

The vegetation of the second reference site in the Slitere National Park in Latvia consisted of much Crepis paludosa, Cirsium oleraceum, Brachythecium rivulare and large patches of typical spring species such as Cardamine amara and Cratoneuron filicinum.

The third reference area with travertine deposition near Mazirbe in Latvia consisted of very lowproductive calcareous fen vegetation with many rare and endangered species such as Primula farinosa, Eriophorum latifolium and Epipactis palustris.

The DCA analysis of vegetation data of the restoration site at Recz and the selected target communities in Złotow and Latvia is shown in Fig. 4. In total we used 44 relevés and 163 species. The analysis shows a clear separation of reference areas and the restoration site. The variation along the main axis ( $\mathrm{x}$-axis; eigenvalue $=0.78$ ) is mainly determined by a difference in species composition between the open calcareous mire at Mazirbe and the degraded (unrestored) forest at Recz. The restoration site at Recz is situated on the left end of the figure, and reflects very eutrophic soil conditions. Złotow is situated in between Recz and Mazirbe. The second axis (y-axis; eigenvalue $=0.39$ ) reflects the difference between the restoration site at Recz and the reference site in the Slitere National Park with active travertine-marl deposition in the alder forest. Eigen values of the third and fourth axes are very low $(<0.15)$. The cumulative percentage of variance explained of the first two axes is 23.3.

\section{Discussion}

Travertine precipitation not restored

Hájek et al. (2002) tried to establish a distinct border between groundwater composition and occurrence of calcareous spring mires of Central-European Carpathians mountains. They found that the minimum calcium concentration needed for occasional $\mathrm{CaCO}_{3}$ precipitation is about $2,250 \mu \mathrm{mol} \cdot \mathrm{l}^{-1}$ and for calcite forming deposits within calcareous spring mires it is about 6,250 $\mu \mathrm{mol} \cdot \mathrm{l}^{-1}$. Smieja and Smieja-Król (2007) indicated much lower values for the Polish Tatra mountains $\left(1,250-1,500 \mu \mathrm{mol} \cdot \mathrm{l}^{-1}\right)$. Almendinger and Leete (1998) suggested that rainfall (dilution) combined with slope inclination can cause under-saturation with respect to calcite and consequently $\mathrm{CO}_{2}$ outgassing will not lead to $\mathrm{CaCO}_{3}$ precipitation.

Grootjans et al. (1999) measured outgassing and corresponding travertine-marl deposition in the surface

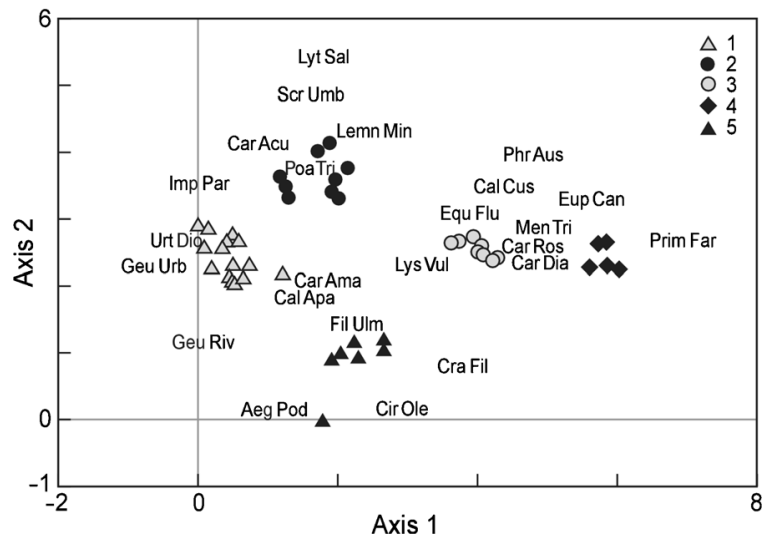

Fig. 4 DCA from the vegetation relevés from the restoration site and reference sites in Poland and Latvia. 1,2 - degraded spring mires at Recz, Poland. 3 - Experiments at restoration site Recz, Poland. 4 - Target vegetation with active travertine deposition at Złotow, Poland; 5 - target vegetation with active travertine deposition at Mazirbe, Latvia. 6 - target vegetation with active travertine deposition in Slitere Forest, Latvia. 
water of small streams in Poland fed by super-saturated groundwater from springs. Values of $\mathrm{CaCO}_{3}$ precipitation in those streams were 10-100 times higher than in the experimental pools at Recz and Złotow, but comparable to values measured in the Latvian mires.

Deposition rates of $\mathrm{CaCO}_{3}$ in the references fen system in Poland (Złotow) were much higher, but still 20-30 times lower than most values mentioned in the literature (Pentecost 2005). Contrary to expectations, temperature appeared not to play a very important role in $\mathrm{CaCO}_{3}$ deposition in our investigated spring mires, since high rates were measured in the shaded forest pools in the Slitere National Park in Latvia (up to $8 \mu \mathrm{g} \cdot \mathrm{cm}^{-2} \cdot \mathrm{d}^{-1}$ ). This forest mire was still actively depositing calcite on the soil surface and on the leaves of moss species (Cratoneuron filicinum and Brachythecium rivulare). This dense carpet slows down water flow and may play an important role in inducing supersaturation by photosynthetic uptake of $\mathrm{CO}_{2}$ (Smieja and Smieja-Król 2007). The deposition on the microscope slides, however, was obviously independent of plant induced processes. Water chemistry therefore appears to be the key factor enabling the deposition of calcite. $\mathrm{Ca}^{2+}$ and $\mathrm{CO}_{2}$ levels in the upwelling water should be sufficiently high, resulting in supersaturation which enables the water to deposit calcium once the $\mathrm{CO}_{2}$ escapes into the air or is used by plants (Pentecost 2005).

In the experimental pools of the restoration site at Recz, conditions for travertine formation were not fulfilled by only rewetting and cutting trees to allow for higher temperatures in the mire. Although some $\mathrm{CaCO}_{3}$ was deposited in the surface water, the rates were extremely low compared to travertine forming springs in the reference areas, and even after 5 years no measurable amounts of $\mathrm{CaCO}_{3}$ were observed in the top layer of the mire.

\section{Goal not reached}

Five years after the restoration measures had been carried out, the mire vegetation of the rewetted spring at Recz showed little resemblance to the target communities in the reference areas in Poland and Latvia. Due to the new occurrence of some moss species and Cardamine amara, a shift occurred towards the Polish target community, but the species composition remained distinctly different from the Latvian reference sites. The rewetting and cutting of trees did result in the reestablishment of some spring mire species, such as
Cardamine amara or Brachythecium rivulare (Cardamino-Montion), but the expected development of low-productive (mesotrophic) vegetation types did not occur. After 5 years, the vegetation at Recz was still very eutrophic. Apparently, the concentration of calcium and iron were not high enough to fix phosphate and makes phosphates less available for plant growth (Richardson and Marshall 1986; Boyer and Wheeler 1989).

Hydrological system changed irreversibly

At Recz several factors prevented the restoration of the former calcareous mire. First, the hydrology has changed considerably since the times of active calcite deposition. At present, calcareous super-saturated groundwater does not reach the mire anymore. It appears to have shifted to lower areas where fish ponds have been established during the last century. The groundwater that is discharging in the fish ponds has calcium values of $3,750 \pm 537 \mu \mathrm{mol} \cdot 1^{-1}$. The groundwater that is now discharging in the restoration site is not supersaturated and has too low $\mathrm{Ca}^{2+}$ and $\mathrm{CO}_{2}$ levels to enable high calcite deposition. This is the major difference against the reference sites in Poland (Złotow) and Latvia, where the upwelling ground water is still supersaturated. Also sulfate concentrations in the surface water at Recz were significantly higher than at Złotow, in both the ground and surface water. Apparently the sulfur in the groundwater at Złotow is in a reduced form (more anaerobic then at Recz). The peat at Recz is also much more decomposed. Oxidation of groundwater therefore already takes place in the peat itself.

\section{Conclusion}

From our results we conclude that it is very difficult, if not impossible, to restore a once degraded calcareous spring system to its original state of calcite deposition and associated vegetation. In the short term, no positive results can be expected from restoration projects in highly degraded systems (see also Koska and Stegmann 2001) with an altered hydrological system that does not supply oversaturated groundwater anymore.

Temperature appears to be of little importance since high calcite deposition was found in the forested spring mire with active calcite deposition in the Slitere National Park in Latvia. 
The findings from this study can have important consequences for the conservation of the remaining calcite depositing mires with rare calciphilous vegetation. Changes in ground water discharge in the source area of a mire could also directly lead to a change in the vegetation (van Loon et al. 2009). Both hydrological and land use changes in the source area of a mire could alter the groundwater composition and the quantity of nutrients in the ground water leading to a change in the mire vegetation. Therefore, preserving still existing and untouched calcareous mires should have priority, because restoring heavily degraded spring mires is hardly an option when groundwater flow paths have been altered.

Acknowledgements We wish to thank Alma Wołejko, Diana Behr, Hildegard Schlöder, Sonja Rieger, and Robert Stanko for guidance and assistance in the field. Pieter Stuyfzand calculated the saturation indices for calcite. Charlotte Deierkauf carried out the $\mathrm{CO}_{2}$ analyses. Their help is greatly acknowledged.

Open Access This article is distributed under the terms of the Creative Commons Attribution 4.0 International License (http:// creativecommons.org/licenses/by/4.0), which permits unrestricted use, distribution, and reproduction in any medium, provided you give appropriate credit to the original author(s) and the source, provide a link to the Creative Commons license, and indicate if changes were made.

\section{References}

Almendinger JE, Leete JH (1998) Peat characteristics and groundwater geochemistry of calcareous fens in the Minnesota River Basin. U.S.A. Biogeoch.43:17-41

Amon JP, Thompson CA, Carpenter QJ, Miner J (2002) Temperate zone fens of the glaciated Midwestern USA. Wetlands 22:301-317

Bedford BL, Godwin KS (2003) Fens of the United States: distribution. characteristics. and scientific connection versus legal isolation. Wetlands 23:608-629

Boyer MLH, Wheeler BD (1989) Vegetation patterns in spring-fed calcareous fens: calcite precipitation and constraints on fertility. J Ecol 77:597-609

Braak CJF ter, Šmilauer P (2002) CANOCO reference manual and CanoDraw for Windows user's guide: software for canonical community ordination (version 4.5). Ithaca NY. USA

Cooper DJ (1995) Water and soil chemistry, floristics, and phytosociology of the extreme rich High Creek fen in South Park Colorado, U.S.A. Can J Bot 74:1801-1811

Dobrowolski R, Hajdas I, Melke J, Alexandrowicz WP (2005) Chronostratigraphy of calcareous mire sediments at Zawadówka (Eastern Poland) and their use in palaeogeographical reconstruction. Geochron 24:69-79

Frank N, Braum M, Hambach U, Mangini A, Wagner G (2000) Warm period growth of travertine during the last interglaciation in southern Germany. Quater research 54:38-48
Futyma RP, Miller NG (2001) Postglacial history of a marl fen: vegetational stability at Byron-Bergen Swamp. New York. Can J Bot 79:1425-1438

Goudie AS, Viles HA, Pentecost A (1993) The late Holocene tufa decline in Europe. The Holocene 3:181-186

Grootjans AP, Swinkels J, Groeneweg M, Wołejko L, Aggenbach C (1999) Hydro-ecological aspects of a Polish spring mire complex (Diabli Skok). Crunoecia 6:73-82

Grootjans AP, Alserda A, Bekker REM, Janáková M, Kemmers RF, Madaras M, Stanova V, Ripka J, Delft B van, Wołejko L (2005) Calcareous spring mires in Slovakia; Jewels in the Crown of the Mire Kingdom. In Steiner, G.M. (ed) Mires. from Siberia to Tierra del Fuego. Stapfia 85:97-115

Grootjans AP, Adema EB, Bleuten W, Joosten H, Madaras M, Janáková M (2006) Hydrological landscape settings of baserich fen mires and fen meadows: an overview. Appl Veg Sc 9: 175-184

Grootjans AP, Jansen AMJ, Šefferová Stanová V (eds) (2012) Calcareous mires of Slovakia; landscape setting, management and restoration prospects. KNNV Publishing. Zeist, NL

Hájek M, Hekera P, Hájkova P (2002) Spring Fen Vegetation and Water Chemistry in the Western Carpathian Flysch Zone. Fol Geobot 37:205-224

Hájková P, Hájek M (2003) Species richness and above-ground biomass of poor and calcareous spring fens in the flysch West Carpathians. and their relationships to water and soil chemistry. Preslia 75:271-287

Hájkova P, Grootjans AP, Lamentowicz M, Rybníčková E, Madaras M, Opravilová V, Michaelis D, Hájek M, Joosten H, Wołejko L (2011) How a Sphagnum fuscum bog changed into a calcareous fen: the remarkable history of a Slovak spring fed mire. J Quart Sc 27:233-243

Herman JS, Hubbard DA jr (eds) (1990) Travertine-marl: stream deposits of virginia. Virginia Division of Mineral Resources. Publication nr 101. Charlottesville. USA

Komor SC (1994) Geochemistry and hydrology of a calcareous fen within the Savage Fen wetlands complex. Minnesota. USA. Geoch Cosmoch Acta 58:3353-3367

Koska I, Stegmann H (2001) Revitalisierung eines Quellmoorkomplexes am Serbitz-Oberlauf. In Succow M, Joosten H (eds) Landschaftsökologische Moorkunde. pp 509-517. Schweizerbart'sche Verlags-Buchhandlung. Stuttgart

Lamers LPM, Smolders AJP, JGM Roelofs (2002) The restoration of fens in the Netherlands. Hydrobiologia 478:107-130

Loon AH van, Schot PP, Griffioen J, Bierkens MFP, Wassen MJ (2009) Palaeo-hydrological reconstruction of a managed fen area in The Netherlands. J Hydrol 378:205-217

Lu G, Zheng C, Donahoe RJ, Berry Lyons W (2000) Controlling processes in a $\mathrm{CaCO} 3$ precipitating stream in Huanglong Natural Scenic District, Sichuan. China. J Hydrol. 230:34-54

Middleton B, Grootjans AP, Jensen K, Olde Venterink H, Margóczi, K (2006) Fen management and research perspectives: an overview. Ecol Studies 191:247-268. Springer Verlag

Miner JJ, Ketterling DB (2003) Dynamic of peat accumulation and marl flat formation in a calcareous fen. Midwestern United States. Wetlands 23:950-960

Pakalne M, Čakare I (2001) Spring vegetation in the Gauja National Park. Latvijas Vegetacija 4:16-33

Pentecost A (2005) Travertine. Springer. 445 pp 
R Core Team (2013) R: A language and environment for statistical computing. R Foundation for Statistical Computing, Vienna, Austria. ISBN 3-900051-07-0 Available at http://www.Rproject.org

Richardson CJ, Marshall PE (1986) Processes controlling movement. storage. and export of phosphorus in a fen peatland. Ecol Monogr 56:279-302

Sakamoto Y, Ishiguro M, Kitagawa G (1986) Akaike information criterion statistics. Reidel, Dordrecht

Smieja A, Smieja-Król B (2007) Springs with active carbonate precipitation in the Polish part of the Tatra Mountains. In Tyc A, Stefaniak K (eds) Karst and Cryokarst.pp 219-226. Univ. of Silesia. Univ. of Wrocław

Succow M, Joosten H (eds) (2001) Landschafsökologische Moorkunde (2nd edition). Schweizerbart'sche Verlagsbuchhandlung. $622 \mathrm{pp}$

Vreeken WJ (1981) Distribution and chronology of freshwater marls between Kingston and Belleville. Ontario. Can J of Earth Sc 18:1228-1239
Wassen MJ, Olde Venterink H, Lapshina ED, Tanneberger F (2005) Endangered plants persist under phosphorus limitation. Nature 437:547-551

Wheeler BD, Giller KE (1982) Species richness of herbaceous fen vegetation in Broadland. Norfolk. in relation to the quantity of above-ground material. $J$ Ecol 70:179-200

Wołejko L, Aggenbach C, Diggelen R van, Grootjans AP (1994) Vegetation and hydrology in a spring mire complex in western Pomerania, Poland. Proc Royal Dutch Acad of Sc 97: 219-245

Wołejko L (2001) Stratigraphy of the soligenous mires in northwestern Poland. Water-Environ Rural Areas 1:83-103 (In Polish with English Summary)

Wright DT, Oren A (2005) Nonphotosynthetic bacteria and the formation of carbonates and evaporites through time. Geomicrobiol J 22:27-53 